的に，雌雄ともに子どあが分散するテナガザル型 のペア社会となわばりが崩壊した結果として位置 づける伊谷純一郎の説であるが，山極は性的活動 性，ディスプレーの様式，「のぞき込み」などの 多義的な社会行動の比較など，最新の資料を駆使 して，それぞれの社会の特徵を抽出しようと試み ている。その詳細についてはこてで紹介する余裕 あなく，興味をお持ちの方は是非とあ本書に目を 通していただきたい。

聞くとてろによれば，山極らがザイールで，ま た京都大学理学部の黒田末寿らがコンゴ共和国で 進めているゴリラとチンパンジーの同所的個体群 の調査は，現在，それぞれの国の政治的状況によ って必ずしあ順調には進渉していないようである。 それぞれ様々な問題があ万うとは思うが，ヒトも ゴリラあ, そしてチンパンジーも平和に暮らせる 環境になってほしいと願わずにはいられない。 なお，文中には敬称を略させていただいた。

注

1) O. ジョンソン, 1963「私は冒険と結婚した」(本 多喜久夫訳）『世界ノンフィクション全集47巻』筑 摩書房, pp. 3-183。なお, ジョンソン夫妻は, ゴ リラの永久保護区の創設を提唱したC・アケレイの 友人であある。

2) 1984 年, 平凡社刊。

3）江原昭善編『サルはどてまで人間か』小学館, pp. $329-364$ 。

4 ) Lancaster, J. B., 1991. A feminist and evolutionary biologist looks at women. Yrbk Phys. Anthropol., 34:1-11.

$5)$ Small, M.F., 1989. Female choice in nonhuman primates. Yrbk Phys. Anthropol., 32: 103-127.
梶 茂樹著

『アフリカをフィールドワークする』

大修館書店

1993 年 224 頁

木 村大 治*

本書は, 梶茂樹氏（以下「梶さん」と呼ばせて あらう) がこの10年ほどの間に書いたエッセーを まとめたものである。

手元に届いた本書をぱらぱらとめくってまず思 ったのは，「お，てれで梶さんの書いたものがダ イジェストで一遍に読めるじゃないか」というて とであった。梶さんは，「人類学的調査では特に そうだと思うが，それがおもしろい論文であるか よ゙うかは，扽しろいテーマを見つけたかどうか で決まる。おむしろい題材を扱ったものは，やは り括しろい」（本書p. 56）と書いているが，氏 の論文を読んでいつも思う感想は，まさにての「お あしろい」である。そういった括もしろい話が, まとめて読めるのはうれしいてとだ。読む前にま ずそう思った。

梶さんは東ザイールの焼畑農耕民テンボの言語 を，長年にわたってインテンシブに調查されてき た。私む，同じザイールの農耕民の研究をしてお り，また多少とも言語にかかわる現象に興味を持 っていることああって，直接・間接に梶さんの仕 事に接してきた。

思い出すのは, テンボランドの近くにある, 梶 さんの拠点にしていたザイール科学研究所の建物 を訪れたときのてとである。そのときは本人はお られなかったが，スワヒリ語も勉強したいと思っ ていた私は（調査はリンガラ語でしていた）， そ てにあったスワヒリ語の教科書をぱらぱらとめく ってみた。それは梶さんの残していった本で，中 にはびっしりと書き込みがしてあった。今ではス ワヒリ語がぺらぺらの梶さんも，最初にきた頃は

* 福井大学教育学部 
この本で一生懸命勉強していたのだろう, とペン の跡を眺めながら思った。

調查の途中で一時帰国したとき, A A 研の研究 室を訪れて，言語の表記法に関する即席の講習を 受けたてとあある。そのとき，本書にも出てくる ピアニカによるトーンの調査法を伝授してもらっ た。不真面目な私は結局実行に移さなかったのだ が。

本書の内容は, バラエティに富んでいる。はじ めてフィールドに入った言語学者の直面した初々 しい戸惑い（1 未知の言語を求めて）に始まり, がちがちの言語学の話 (2フィールド言語学から歴 史言語学へ，3比較研究法)，テンボの生活に関 する文化人類学的な話 (6 結婚はしたいけれど ザイール・テンボ族当世若者事情，8マンダイマ 一女性の乙わい呪術の巻, など), 多言語国家の社 会言語学的考察 (13 植民地化と言語政策, そして文 字 — ザイールの場合, 14モンゴ人のジレンマ— ザイール国語化問題の一断章, など), 諺や個人名の 話 (16 テンポ族の命名, など) と続く。さらに，リ ンガラ・ミュージックの翻訳 (18 人はリンガラ語 で何を歌っているかーザイール現代音楽瞥見), ザ イール人の映画監督へのインタビュー（21 映画『人 生は楽し』のムエゼ・ンガングラ監督に聞く)と, ほとんど「でった煮」の様相を呈していると言っ てあよい。しかしそれらは不思議に，ばらばらな 印象を与えない。なぜかいえば,ひとつは当然 それらに「言語」というバックボーンが通ってい るからであり，そしてあうひとつは，よ゙の行間か ら屯共通して，「俺はザイールが好きだ」という 梶さんの心持ちが感じられるからに違いない。

梶さんと言えばテンボである。もちろんテンボ 語の他にむ十いくつの言語を調査されているが, やはり帰っていく原点はテンボのようである。乙 ういったひとつの民族，ひとつの言語への徹底的 な乙だわりについて，梶さんは次のように書いて いる。「一般的に言って, 部族語というのはその 構造がきわめて複雑で，いくら調査してもそのす べてを汲み尽くすということはありえない。その 理由は, 言語 一あるいは言語活動一というあの は多か机少なか放文化の存在を前提にして成り立っ
ているのであるが, 部族語が拠って立つ部族文化 というものはきわめて奥が深く，しかもそれはあ くまで個別文化的な奥の深さだからである」（p. 105)。乙のことは私も, 実際自分でひとつの民族 というあのを調查してみて, しみじみと思う。言 葉を少し理解しはじめると，とんであなく深いさ まざまな世界が，そこに見えてくる。本書は我々 に，そういった言語世界の広がりを䙼かせてくれ る。

ザイールに対する梶さんの気持ちは，ザイール 人と長くつきあってきた私には，痛いほどよくわ かる。共通の部分が多すぎて, 感想が「そうそう, そうなんだよね」と喜んでしまうだけになりかね ない。その意味で, 私は評者として適当ではない のかむしれない。アフリカの毒, とよく言うけれ ど, ザイールの毒はその中でも最も強烈な部類に 属すると思う。その強烈なやつに最初に当たると, アフリカのほかの国々の人たちが, ジェントルに, しかしなんとなく物足りなく感じるようになって しまうのである。

私は先日, カメルーンで短期の調査をしてきた が, 帰りのドゥアラからキンシャサまでの飛行機 の中で，三人組のザイール人と乗り合わせた。 皮のジャケットに角度のきついサングラスという いでたちで, どうみてあちょっとあぶないミュー ジシャン, という雾囲気だった。かれらは私の後 ろの席で, 延々とリンガラ語で喋りつづけた。あ のキンシャサ風の, nazali をnaza' と略す, 早く てフランス語のたくさん交じったリンガラである。 小耳にはさむと他愛むない話をしているのだが， それをとんでもない大声で, どうにあ楽しくてた まらないと言ったふうに喋るのである。私の前の 席にいたドィッ人の若い女性の二人連れは，あれ は一体何? と言いたげに何度む後ろを振り返って いた。私む久しぶりのリンガラのシャワーを浴び て，しばらくは心地好かったが，キンシャサでか れらが降りるとほっとせざるをえなかった。

ザイールをやっているあのが共通に持つ，乙う いった「ザイール人の毒」に対するアンビバレン トな思い，それが，本書の端々から感じられてな らない。 
最後に，私なりの著者への期待を述へてみたい。 てれは私の関心に重なってくるのだが，テンボた ちは言語を用いて，日常どういったインターラク ションを展開しているかというてとを知りたくな るのである。この問題は今後の人類学研究の大き なテーマであろうが，実際そういうことを調査し ようとすると，部族語という壁がどうしょうもな く立ちはだかってくる。要するに，我々はかれら が日常絶え間なく早口で喋っている内容を, 逐語 的にも文脈的にも，本人たちほどには理解できな いのである。

人類学者たちが不器用に取り組んでいるての問 題を，「プロの」言語学者である梶さんならどの ように扱うのだろうか。氏は少なくとも，言語学 に関して素人の私よりは有利な地点にいるのに違 いない。その腕でテンボの日常会話の世界を活写 して見せてほしい。そんなてとを考えながら本書 を読み終えた。

岡倉登志, 北川勝彦著

『日本一アフリカ交流史 一 明治期から 第二次世界大戦期まで—』

同文館

1993 年

\section{森川純 $*$}

日本のアフリカ研究において, 事実上, 放置さ れたままのテーマがある。それは，アフリカと日 本の過去と現在の関係に対するものである。特に 過去の両者間の関係についての批判的・分析的な 検討，より具体的には，(1)いつ，どのように関係 が樹立・発展され，(2)関係の内容なり性格は，い かなるもので，さらにそれが(3)現在の関係にどの ような影響を与えているのか，といったてとはほ とんどなされていない。

そうした知的状況を生み出した要因としては,

* 明治大学文学部
アフリカと日本との関係は, 歴史的に浅く, 研究 対象として正面から取り上げるほどの重要性屯緊 急性も持たない, というイメージなり判断が一般 に定着しているてと。

さらに“日本は西欧諸国と違って,アフリカに 植民地を領有しなかったゆえに，手が污れていな い”之いう政府・外務省及び一部の研究者の主張 による影響が指摘されよう。

そうした要因の当否はともかくとして，アフリ 力と日本との歴史的関係に対する研究が不十分な ままに放置されている事態は以下の観点から言っ て屯，やはり奇妙かつ不健康といわざるをえない。 というのは第一に, 本書がヴィヴィドに提示し ているように，アフリカー日本関係は，一般に信 じられているとてろと違って比較的長い歴史と規 模・ひろがりを有しているてと。

第二に，昨年の 10 月上旬に日本政府をホストと して開催された，アフリカ経済再建と民主化の支 援を目的とした一大国際会議, 『アフリカ開発会 議』（TICAD）に劇的に示されたように，アフリ カに拈ける日本のプレゼンスは急速に増大してい るからである。

アフリカへの支援を実りあるものとするならば, 援助の強化を叫ぶことで満足するてとなく，日本 のアフリカとのてれまでの関係を多面的, 総合的 に再検討しそてから教訓を学び, 生かす作業を行 う必要があろう。

まえがきが長くなってしまったが，それは学問 上のみならず, アフリカとの互恵的関係の構築, といった課題実現の上にも持つ本書公刊の意義を 明らかにしたかったからである。

次に本書の構成を紹介しておてう。

第 1 章 日本人のアフリカ観一明治維新から第二 次世界大戦期まで

$\mapsto \quad$ 明治前半期のアフリカ観

( 日清戦争直後のアフリカ観

曰 第一次世界大戦後のアフリカ観

第 2 章 日本とエチオピア

$\mapsto$ 日本・エチオピア関係史

二エチオピアの「近代化」一日本の「近代化」 と比較して 